\title{
STUDI KINETIKA REAKSI PEMBUATAN BIODIESEL DARI MINYAK NYAMPLUNG MENGGUNAKAN IRADIASI MICROWAVE
}

\author{
Nisa Nurhidayanti \\ Sekolah Tinggi Teknologi Pelita Bangsa \\ nisa.kimia@pelitabangsa.ac.id
}

\begin{abstract}
Abstrak -Minyak nyamplung (Calophyllum inophyllum Linn) adalah salah satu bahan baku yang potensial untuk produksi biodiesel karena kandungan minyaknya yang tinggi. Minyak nyamplung mengandung asam lemak bebas yang tinggi, proses pretreatment dalam penelitian ini dapat mereduksi asam lemak bebas dari $27,978 \%$ menjadi $1,269 \%$ sehingga minyak dapat dilanjutkan pada proses transesterifikasi. Iradiasi microwave digunakan pada proses transesterifikasi sebagai metode alternatif yang lebih cepat dibandingkan dengan metode refluks konvensional. Tujuan penelitian ini untuk mengidentifikasi metil ester dalam produk, mengkaji kinetika reaksi pembuatan biodiesel dan mengkaji pengaruh penggunaan iradiasi microwave terhadap energi aktivasi dan laju reaksi transesterifikasi dibandingkan dengan metode konvensional. Power microwave (100, 200 dan 400W), waktu iradiasi $(5,7,10,12$ dan 15 menit) dan suhu reaksi $\left(50,55,60,65\right.$ dan $\left.70^{\circ} \mathrm{C}\right)$ digunakan sebagai parameter penelitian. Kondisi operasi terbaik menggunakan power microwave $200 \mathrm{~W}$ pada suhu $65^{\circ} \mathrm{C}$ selama 5 menit, yield biodiesel maksimal sebesar $84,62 \%$ dan sifat fisik biodiesel telah memenuhi standar SNI 04-7182-2006, ASTM 6751-02 dan EN-14214. Biodiesel nyamplung mengandung $30,23 \%$ metil oleat, $25,76 \%$ metil linolelaidat, $19,21 \%$ metil palmitat, $15,75 \%$ metil stearat, $2,11 \%$ metil lignocerat, $1,41 \%$ metil eicosanoic, $0,54 \%$ metil behenate dan $0,37 \%$ metil palmitoleat. Biodiesel nyamplung dengan iradiasi microwave memiliki energi aktivasi (Ea) sebesar 2579,834 J/mol, faktor tumbukan (A) sebesar 1,0161 L/mol menit, laju reaksi transesterifikasi $\left(r_{t}\right)=1,0161 \mathrm{e}^{(-2579,834 / \mathrm{RT})}[\mathrm{ME}]$ dan waktu reaksi selama 5 menit. Sedangkan biodiesel nyamplung dengan metode konvensional memiliki energi aktivasi (Ea) sebesar 4831,265 $\mathrm{J} / \mathrm{mol}$, faktor tumbukan (A) sebesar $0,3772 \mathrm{~L} / \mathrm{mol}$, laju reaksi transesterifikasi $\left(\mathrm{r}_{\mathrm{t}}\right)=0,3772 \mathrm{e}^{(-4831,265 / \mathrm{RT})}[\mathrm{ME}]$ dan waktu reaksi selama 30 menit. Hasil penelitian menunjukkan penggunaan iradiasi microwave dapat meningkatkan laju reaksi transesterifikasi, menurunkan energi aktivasi dan mengurangi waktu reaksi menjadi 1/6 kali lebih cepat dibandingkan metode konvensional.
\end{abstract}

Kata kunci: biodiesel, iradiasi microwave, kinetika reaksi, minyak nyamplung

Abstract - Nyamplung (Calophyllum inophyllum Linn) is an potential feedstock for biodiesel production because of its high oil content. As nyamplung oil contains high free fatty acid, a pretreatment process in this research was carried out to reduce the amount of FFA from $27.498 \mathrm{wt} \%$ to $1.269 \mathrm{wt} \%$ so that the oil can be resumed in the transesterification process. Microwave irradiation is used in the transesterification process as an alternative method that is faster than the conventional reflux method.The purpose of this research was to study identify methyl ester in the product, examine the kinetics of biodiesel and assess the effect of using microwave irradiation to activation energy and the rate of transesterification reactions compared to conventional methods. Microwave power $(100,200$ and $400 \mathrm{~W})$, reaction time $\left(5,7,10,12\right.$ and 15 minutes) and reaction temperature $\left(50,55,60,65\right.$ and $\left.70^{\circ} \mathrm{C}\right)$ were selected as experimental parameters. The optimum conditions for transesterification process is using microwave power of $200 \mathrm{~W}$ at $65^{\circ} \mathrm{C}$ for 5 minutes to obtain yield biodiesel of $84.62 \%$ and physical properties biodiesel meet the standard of SNI 04-7182-2006, ASTM 6751-02 and EN-14214. Nyamplung biodiesel contains about 30.23\% of methyl oleic, $25.76 \%$ of methyl linolelaidate, $19.21 \%$ of methyl palmitic, $15.75 \%$ of methyl stearic, $2.11 \%$ of methyl lignoceric, $1.41 \%$ of methyl eicosanoic, $0.54 \%$ of methyl behenate and $0.37 \%$ of methyl palmitoleic. Nyamplung biodiesel preparation using microwave irradiation has the activation energy (Ea) of $2579.834 \mathrm{~J} / \mathrm{mol}$, collision factor (A) of $1.0161 \mathrm{~L} / \mathrm{mol} \mathrm{min}$, the rate of transesterification reaction $\left(r_{t}\right)=1,0161$ e $(-2,579.834 / R T)$ [ME] and reaction time of 5 minutes. Nyamplung biodiesel preparation using the conventional method has the activation energy (Ea) of 4831.265 $\mathrm{J} / \mathrm{mol}$, collision factor (A) of $0.3772 \mathrm{~L} / \mathrm{mol}$ and the rate of the transesterification reaction $\left(r_{t}\right)=0.3772$ e $\left(\left(^{-4.831 .265 /}\right.\right.$ $\left.{ }^{R T}\right)[M E]$ and reaction time of 30 minutes. The results showed the use of microwave irradiation increases the rate of transesterification reaction, lowering the activation energy and reduce the reaction time becomes 1/6 times faster than conventional methods.

Keywords: biodiesel, microwave irradiation, , reaction kinetic, Calophyllum inophyllum oil

\section{PENDAHULUAN}

Kebutuhan bahan bakar minyak dari tahun ke tahun terus meningkat. Indonesia sebagai salah satu negara di ASEAN yang sampai saat ini penggunaan sumber energinya masih sangat bergantung pada bahan bakar fosil. Energi fosil yang digunakan sebagai sumber daya energi utama di Indonesia terdiri dari minyak, gas dan batubara. Berdasarkan rasio cadangan produksi sumber energi fosil, potensi pemanfaatan energi fosil yang paling tinggi adalah penggunaan batubara, dalam waktu sekitar 70 tahun lagi persediaannya akan habis, sedangkan energi fosil yang menempati peringkat 
kedua yaitu sumber daya gas yang diperkirakan masih dapat bertahan hingga sekitar 28 tahun lagi. Sumber energi fosil berupa minyak merupakan sumber energi yang potensinya paling kecil, yaitu masih dapat dimanfaatkan dalam jangka waktu sekitar 7 tahun lagi, apabila tidak ditemukan cadangan baru dan tidak ada usaha untuk menggantikan energi fosil dengan energi alternatif yang tersedia di alam (Sugiyono, 2014). Salah satu cara untuk meminimalisir ketergantungan terhadap bahan bakar fosil dan agar dapat memenuhi syarat lingkungan global adalah dengan mengembangkan biodiesel sebagai bahan bakar terbarukan yang ramah lingkungan dan berkelanjutan.

Bahan baku pembuatan biodiesel yang digunakan di Indonesia adalah minyak kelapa sawit dan minyak jarak pagar. Penggunaan minyak kelapa sawit sebagai bahan baku biodiesel dinilai kurang efisien karena mengganggu ketahanan pangan. Sedangkan minyak jarak pagar masih menjadi kendala karena rendahnya produktivitas tanaman jarak pagar. Salah satu tanaman non pangan yang memiliki potensi menghasilkan randemen biodiesel yang tinggi adalah nyamplung (Calophyllum inophyllum Linn). Minyak nyamplung adalah minyak non pangan dan menjadi bahan baku penting untuk produksi biodiesel.

Pemilihan teknologi untuk proses pembuatan biodiesel sangat penting karena biodiesel merupakan suatu sumber energi terbarukan sehingga proses pembuatan biodiesel harus memperhatikan efisiensi prosesnya. Iradiasi microwave adalah salah satu metode yang dapat mempercepat terjadinya reaksi transesterifikasi, hal ini dikarenakan energi dapat langsung ditransfer ke reaktan tanpa media perantara sehingga proses transfer panas akan lebih efektif jika dibandingkan dengan metode refluks konvensional, sehingga proses terjadinya reaksi membutuhkan waktu yang lebih singkat. Penggunaan iradiasi microwave dalam proses transesterifikasi adalah metode terbaik untuk mempersingkat waktu reaksi dan meningkatkan yield pada produksi biodiesel (Motasemi \& Ani, 2012). Penelitian mengenai kinetika reaksi menggunakan teknik konvensional dua tahap telah dilakukan sebelumnya oleh Sahirman (2009), namun belum diteliti menggunakan iradiasi microwave. Oleh karena itu, perlu dikaji kinetika reaksi pembuatan biodiesel dari minyak nyamplung menggunakan iradiasi microwave.

Tujuan dari penelitian ini adalah untuk mengidentifikasi metil ester yang terkandung dalam biodiesel dari minyak nyamplung menggunakan iradiasi microwave dan mengkaji kinetika reaksi transesterifikasi minyak nyamplung menggunakan iradiasi microwave dengan katalis dan kinetika reaksi transesterifikasi minyak nyamplung metode konvensional dengan katalis.

Penelitian ini diharapkan dapat bermanfaat untuk mengurangi ketergantungan penggunaan bahan bakar fosil sehingga masyarakat dapat memanfaatkan potensi sumber daya minyak non pangan, khususnya minyak nyamplung untuk menghasilkan bahan bakar alternatif ramah lingkungan, menciptakan infrastruktur pekerjaan baru dan dapat meningkatkan kesejahteraan masyarakat, serta dapat berkontribusi dalam upaya menangani permasalahan mengenai menipisnya cadangan bahan bakar fosil dengan menyediakan alternatif bahan bakar yang dapat diperbaharui /renewable dan ramah lingkungan serta mengatasi kerugian aspek sosial ekonomi dari teknologi biodiesel saat ini, mengatasi tantangan perubahan iklim dan meningkatkan ketahanan energi nasional.

\section{KAJIAN PUSTAKA DAN PERUMUSAN HIPOTESIS}

Bahan bakar fosil konvensional berkontribusi pada pemanasan global melalui peningkatan gas rumah kaca (GRK). Sehingga diperlukan energi alternatif, terbarukan, berkelanjutan, efisien, biaya produksi rendah, dengan emisi yang lebih rendah (Demirbas, 2009). Pemilihan bahan baku yang sesuai adalah masalah penting untuk memastikan biaya produksi biodiesel yang rendah. Bahan baku biodiesel harus memenuhi persyaratan untuk produksi biodiesel dengan biaya produksi rendah dan produksi skala besar (Silitonga et al, 2013).

Secara umum, bahan baku biodiesel dapat dikategorikan menjadi empat kelompok: (i) minyak nabati pangan: kedelai, kelapa sawit, bunga matahari, safflower, rapeseed, kelapa dan kacang; (ii) minyak non pangan: jatropha, karanja, mahua, biji rami, biji kapas, nimba, camelina dan nyamplung; (iii) limbah atau minyak daur ulang: minyak goreng bekas, minyak pomace; dan (iv) lemak hewan: lemak daging sapi, lemak babi, lemak ayam dan minyak ikan (Kumar et al, 2013). Minyak non pangan, limbah atau minyak daur ulang serta lemak hewan merupakan bahan baku biodiesel generasi kedua. Produksi biodiesel dari minyak non pangan lebih mudah dibudidayakan di lahan yang tidak cocok untuk tanaman pangan dengan biaya yang jauh lebih rendah dibandingkan tanaman minyak pangan dan pertumbuhan tanaman ini mengurangi konsentrasi $\mathrm{CO}_{2}$ di atmosfer (BankoviüIliü et al, 2012).

Biodiesel pada dasarnya diproduksi dengan transesterifikasi menggunakan alkohol dengan katalis basa. Proses ini cocok untuk minyak dengan kandungan free fatty acid (FFA) yang sangat rendah untuk menghindari pembentukan sabun. Minyak Calophyllum inophyllum Linn mengandung FFA yang tinggi ( 27 wt.\%), oleh karena itu tidak dapat dikonversi secara langsung menjadi biodiesel mengikuti reaksi transesterifikasi berkatalis basa secara konvensional. Metode dua atau tiga tahap telah diterapkan untuk menghasilkan biodiesel berkualitas tinggi dari bahan baku ini oleh beberapa peneliti. Misalnya, Sahoo et al., (2009) menggunakan proses transesterifikasi tiga tahap untuk menghasilkan biodiesel dari minyak $C$. Inophyllum dengan bilangan asam awal $44 \mathrm{mg} \mathrm{KOH} / \mathrm{g}$. Venkanna \& Reddy (2009) 
meneliti biodiesel dari minyak Calophyllum inophyllum Linn melalui pretreatment esterifikasi berkatalis asam, tahap transesterifikasi dan post treatment. SathyaSelvabala et al (2011) melakukan proses dua tahap untuk menghasilkan biodiesel dari minyak nyamplung menggunakan katalis asam padat dimodifikasi zeolite untuk langkah pretreatment diikuti oleh reaksi transesterifikasi berkatalis $\mathrm{KOH}$.

Penelitian Prihanto dkk, 2013 tentang pembuatan biodiesel dari minyak nyamplung melalui transesterifikasi dua tahap menunjukkan bahwa semakin besar rasio molar metanol terhadap minyak dapat meningkatkan yield biodiesel. Suhu reaksi transesterifikasi yang semakin tinggi juga berbanding lurus dengan yield biodiesel yang dihasilkan. Konsentrasi katalis basa kalium hidroksida yang digunakan untuk menghasilkan yield maksimal adalah pada konsentrasi katalis $\mathrm{KOH}$ sebesar 1,25 \%. Hasil penelitian menunjukkan bahwa melalui transesterifikasi dua tahap dapat meningkatkan yield biodiesel dari minyak biji nyamplung. Kondisi terbaik pembuatan biodiesel dari minyak biji nyamplung adalah pada suhu $60^{\circ} \mathrm{C}$, rasio metanol terhadap minyak nyamplung sebesar 8:1 dan konsentrasi katalis $\mathrm{KOH}$ $1,25 \%$. Yield biodiesel sebesar 92,98\%. Biodiesel yang dihasilkan telah memenuhi standar SNI 04-71822006 dengan kadar metil ester 99,61 \% sebagai bahan bakar mesin diesel.

Penggunaan microwave dilakukan oleh Priambodo et al (2015) pada reaksi transesterifikasi minyak goreng segar dan minyak goreng bekas. Faktor utama yang mempengaruhi proses transesterifikasi adalah rasio molar metanol terhadap minyak, jumlah katalis dan waktu reaksi. Penggunaan iradiasi microwave menghasilkan konversi yield biodiesel maksimal sebesar 99\% untuk produksi biodiesel dari minyak goreng segar dan $93 \%$ biodiesel dari minyak goreng bekas dengan rasio molar metanol dan minyak sebesar 6: 1 , SrO sebagai katalis $(1,85 \%)$ dan waktu reaksi 40 detik dan 3 menit. Hasil penelitian menunjukkan bahwa penerapan energi gelombang microwave membuat reaksi lebih cepat, tahapan lebih mudah, terjadi peningkatan laju reaksi dan meningkatkan proses pemisahan. Waktu reaksi berkurang menjadi 40 detik untuk minyak goreng segar dan 3 menit untuk minyak goreng bekas dibandingkan dengan metode konvensional selama 150 menit, karena dengan menggunakan teknik microwave, tidak diperlukan pretreatment esterifikasi.

Hasil penelitian Ridho, dkk (2014) menunjukkan bahwa penggunaan iradiasi microwave menggunakan katalis kalsium oksida $(\mathrm{CaO})$ untuk proses transesterifikasi minyak nyamplung dapat menghasilkan biodiesel yang memenuhi standar SNI dengan densitas sebesar $0,886 \mathrm{~g} / \mathrm{ml}$, cetane index 46,95 viskositas kinematik sebesar 4,545 cSt, dan flash point $>200^{\circ} \mathrm{C}$. Kondisi operasi terbaik pada daya microwave $100 \mathrm{~W}$, konsentrasi katalis $4 \%(\mathrm{w} / \mathrm{w})$ serta rasio mol metanol terhadap minyak 9:1 dapat menghasilkan yield biodiesel sebanyak 94\% (massa biodiesel/massa minyak nyamplung).

Studi kinetika reaksi transesterifikasi minyak kelapa sawit telah dilakukan Jimmy (2012) menggunakan model kinetika reaksi transesterifikasi orde dua menunjukkan bahwa semakin tinggi suhu operasi transesterifikasi kelapa sawit menyebabkan peningkatan laju reaksi. Laju reaksi transesterifikasi pada suhu $60^{\circ} \mathrm{C}$ yaitu sebesar $1,58 \times 10^{-2}$ mol. $L^{-1}$.menit ${ }^{1}$ dengan konstanta laju reaksi ke kanan $\mathrm{k}_{1}=1,68 \times 10^{-4}$ L.mol ${ }^{-1}$.menit ${ }^{-1}$ dan konstanta laju reaksi ke kiri $\mathrm{k}_{2}=$ $5,19 \times 10^{-5}$ L.mol $^{-1}$.menit ${ }^{-1}$, dan konversi FAME (Fatty Acid Methyl Ester) sebesar 86,61\%. Hasil penelitian menunjukkan semakin tinggi konstanta laju reaksinya maka semakin tinggi pula peningkatan \% FAME, karena metanol akan semakin reaktif seiring dengan mendekati titik didih metanol.

Penelitian Jain, et al 2011 mengkaji kinetika reaksi dua tahap dari minyak goreng bekas dengan kadar FFA tinggi. Kondisi optimal rasio metanol terhadap minyak 3: $7(\mathrm{v} / \mathrm{v})$, suhu $65^{\circ} \mathrm{C}$ untuk esterifikasi asam dan 50 ${ }^{\circ} \mathrm{C}$ untuk transesterifikasi basa, $400 \mathrm{rpm}$ dan konsentrasi katalis $\mathrm{H}_{2} \mathrm{SO}_{4} \quad 1 \%$ (w/w) dan $\mathrm{NaOH} 1 \%$ (w/w). Konstanta laju reaksi esterifikasi dan transesterifikasi sebesar 0,0031 $\mathrm{min}^{-1}$ dan 0,0078 $\mathrm{min}^{-}$ 1. Hasil metil ester dari esterifikasi dan transesterifikasi sebesar $21,5 \%$ dan 90,6\%. Energi aktivasi reaksi transesterifikasi sebesar 88.764,53 J/mol. Energi yang rendah berguna untuk produksi biodiesel dari minyak FFA tinggi dan memberikan kesempatan untuk daerah terpencil melalui listrik pedesaan. Proses ini dapat diaplikasikan secara luas untuk mengkonversi minyak dengan FFA tinggi, khususnya minyak non pangan.

Studi kinetika lain yaitu transesterifikasi minyak nyamplung yang telah dilakukan oleh Sahirman, dkk (2009). Reaksi transesterifikasi menggunakan reaktor batch mengikuti reaksi orde satu dengan rasio molar metanol terhadap minyak 6:1, konsentrasi katalis $\mathrm{NaOH} 1 \%$ wt, kecepatan pengadukan $400 \mathrm{rpm}$, waktu 30 menit dan suhu $29^{\circ} \mathrm{C}, 45^{\circ} \mathrm{C}, 60^{\circ} \mathrm{C}$ dan $70^{\circ} \mathrm{C}$. Hasil penelitian menunjukkan bahwa konstanta laju reaksi transesterifikasi pada suhu $29^{\circ} \mathrm{C}, 45^{\circ} \mathrm{C}, 60^{\circ} \mathrm{C}$ dan 70 ${ }^{\circ} \mathrm{C}$ berturut-turut adalah $5,46 \times 10^{-2}$ menit, $6,63 \times 10^{-2}$ menit, $8,83 \times 10^{-2}$ menit dan $11,74 \times 10^{-2}$ menit. Energi Aktivasi (Ea) sebesar 3870,5 cal/mol dengan laju reaksi transesterifikasi $(\mathrm{r})=32,23 \mathrm{e}^{(3870,5 / \mathrm{RT})}[\mathrm{ME}]$. Pada kondisi isotermal suhu $60^{\circ} \mathrm{C}$ dengan harga $\mathrm{k}=8,83 \times 10^{-}$ 2 menit, untuk menghasilkan metil ester sebesar 95,17\% dibutuhkan waktu selama 15,27 menit.

Berdasarkan penelitian terdahulu, maka perlu dikaji kinetika reaksi pembuatan biodiesel dari minyak nyamplung menggunakan iradiasi microwave.

\section{METODE PENELITIAN}

Bahan dan Alat

Bahan yang digunakan 
Bahan baku yang digunakan dalam penelitian ini adalah minyak nyamplung (Calophyllum inophyllum Linn.) yang diperoleh dari Koperasi Jarak Lestari Cilacap Jawa Tengah. Bahan kimia yang digunakan antara lain metanol teknis, etanol $96 \%$ dari toko kimia $\mathrm{CV}$. Indrasari Semarang, kalium hidroksida $(\mathrm{KOH})$ pa dari Merck KgaA-Germany, asam oksalat $\left(\mathrm{H}_{2} \mathrm{C}_{2} \mathrm{O}_{4} 2 \mathrm{H}_{2} \mathrm{O}\right)$ extrapure dari Merck KgaA-Germany, asam sulfat $\left(\mathrm{H}_{2} \mathrm{SO}_{4}\right)$ pa, asam fosfat $\left(\mathrm{H}_{3} \mathrm{PO}_{4}\right)$ pa dan asam asetat $\left(\mathrm{CH}_{3} \mathrm{COOH}\right)$ pa yang diperoleh dari Laboratorium C-BIORE Universitas Diponegoro Semarang dan aquades dari Laboratorium Mer-C Universitas Diponegoro Semarang.

\section{Alat yang digunakan}

Peralatan yang digunakan: microwave merk Elektrolux model EMM2007X type MM820AYC-PA0C, satu rangkaian reaktor esterifikasi-transesterifikasi (labu mulut tiga, pendingin balik, termometer, pengaduk, statif, klem penjepit dan hot plate stirrer), oven vakum, alat distilasi, kompor listrik, pengaduk, erlenmeyer, pipet volum, labu ukur, $\mathrm{pH}$ meter, neraca, pipet, corong pemisah, buret, viskosimeter oswald, piknometer, GC (Gas Chromatography) merk Hewlett Packard 5890 Series II dan GC-MS Shimadzu-QP2010S.

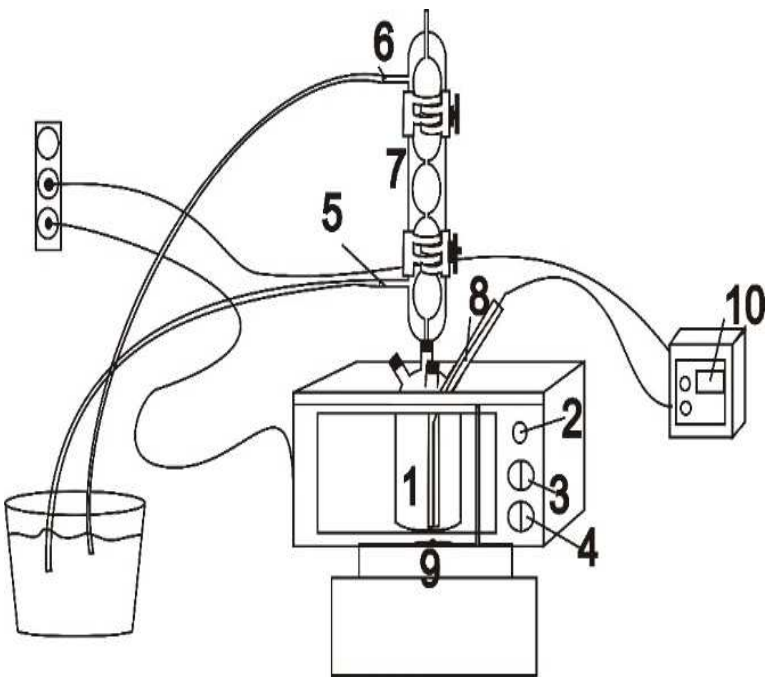

Gambar 1. Rangkaian Alat Penelitian

Keterangan alat:
1.) Reaktor
2). Tombol on/off microwave
3). Kontrol daya
4). Kontrol waktu
5). Aliran air pendingin masuk
6). Aliran air pendingin keluar
7). Kondensor refluks
8). Termometer
9). Magnetic stirrer
10). Kontrol suhu

\section{Prosedur Penelitian}

Produksi biodiesel dilakukan dalam dua langkah mekanisme reaksi, yaitu tahap pretreatment dan reaksi transesterifikasi:

\section{Tahap Pretreatment}

Minyak nyamplung dari Koperasi Jarak Lestari Cilacap minyak memiliki kadar free fatty acid (FFA) tinggi sebesar 27,498\%, sehingga diperlukan tahap pretreatment sebelum transesterifikasi. Tahap pretreatment dimulai dengan deguming untuk menghilangkan getah (gum) fosfolipid, glikolipid, liprotein, resin fosfatida dan impurities dan tahap esterifikasi dan netralisasi yang bertujuan untuk menurunkan kadar FFA dan air agar dapat dilanjutkan ke tahap transesterifikasi.

a. Tahap Deguming

Minyak nyamplung sebanyak $400 \mathrm{~mL}$ dipanaskan hingga suhu $80^{\circ} \mathrm{C}$ kemudian ditambahkan asam fosfat sebanyak $8 \mathrm{~mL}(2 \%$ v/v) minyak nyamplung, sambil diaduk selama 15 menit. Kemudian minyak didiamkan dalam corong pisah sampai gum dan kotoran terpisah dari minyak.

b. Esterifikasi dengan katalis asam

Menurut Zhang et al (2010) rasio minyak terhadap metanol efektif untuk proses esterifikasi adalah 6,82:1-54,55:1. Pada penelitian ini menggunakan rasio molar minyak terhadap metanol 8:1. $300 \mathrm{~mL}$ minyak nyamplung hasil deguming dipanaskan dalam labu leher tiga hingga suhu $60{ }^{\circ} \mathrm{C}$ kemudian ditambahkan $6 \mathrm{~mL} \mathrm{H}_{2} \mathrm{SO}_{4}$ sebagai katalis $(2 \%$ $\mathrm{v} / \mathrm{v})$ dan $82 \mathrm{~mL}$ metanol dengan kecepatan pengadukan $400 \mathrm{rpm}$ selama 60 menit pada suhu $60^{\circ} \mathrm{C}$. Kemudian, dilakukan pemisahan antara metanol, minyak dan air menggunakan corong pisah. Minyak yang terbentuk pada esterifikasi pertama masih memiliki FFA $13,19 \%$ sehingga perlu dilakukan esterifikasi kedua. $300 \mathrm{~mL}$ minyak hasil esterifikasi 1 dipanaskan hingga suhu $60{ }^{\circ} \mathrm{C}$ kemudian ditambahkan $6 \mathrm{~mL} \mathrm{H}_{2} \mathrm{SO}_{4}$ sebagai katalis $(2 \%$ $\mathrm{v} / \mathrm{v})$ dan $42 \mathrm{~mL}$ metanol dengan kecepatan pengadukan $400 \mathrm{rpm}$ selama 60 menit pada suhu $60^{\circ} \mathrm{C}$. Selanjutnya minyak dicuci dengan aquades bersuhu $40^{\circ} \mathrm{C}$ dikeringkan dalam oven pada suhu $105^{\circ} \mathrm{C}$ untuk menurunkan kadar air.

c. Netralisasi

Memanaskan $250 \mathrm{~mL}$ minyak hasil esterifikasi pada suhu $60^{\circ} \mathrm{C}$, kemudian ditambahkan $5 \mathrm{~mL}$ larutan $\mathrm{KOH} 1 \mathrm{~N}(2 \% \mathrm{v} / \mathrm{v})$ sambil diaduk selama 2,5 menit. Ke dalam corong pisah minyak tersebut dimasukkan dan ditambah air dengan suhu $70{ }^{\circ} \mathrm{C}$ sebanyak $25 \mathrm{~mL}$ dan dibiarkan agar air dan minyak dapat dipisahkan. Kemudian dilakukan proses pencucian ulang sampai air cucian bersifat netral, lalu dikeringkan dalam oven pada suhu $85^{\circ} \mathrm{C}$ selama 30 menit (Prihanto dkk., 2013).

\section{Transesterifikasi}

a. Transesterifikasi secara konvensional

Sebanyak 1,874 gram katalis $\mathrm{KOH}$ (1\%wt) dicampurkan dengan $86 \mathrm{~mL}$ metanol dalam bak air termostatik yang dilengkapi pengaduk 
magnetik selama 5-10 menit. $200 \mathrm{~mL}$ minyak nyamplung dimasukkan kedalam reaktor berisi campuran katalis dan metanol dilanjutkan dengan pemanasan di dalam reaktor transesterifikasi hingga suhu $65{ }^{\circ} \mathrm{C}$. Reaksi dilakukan dengan kecepatan pengadukan 400 rpm pada tekanan 1 atm, rasio molar metanol terhadap minyak 8:1 selama 30 menit dengan pengambilan sampel setiap 6 menit sekali. Reaksi ini dilakukan variasi suhu $50{ }^{\circ} \mathrm{C}, 55^{\circ} \mathrm{C}, 60^{\circ} \mathrm{C}, 65^{\circ} \mathrm{C}$ dan $70^{\circ} \mathrm{C}$. Proses transesterifikasi ini akan memperoleh data konsentrasi metil ester selama reaksi berlangsung. Selanjutnya, campuran dimasukkan ke dalam corong pisah dan didiamkan agar gliserol dapat dipisahkan dari lapisan biodiesel. Lapisan atas (biodiesel) dicuci dengan aquades $\pm 50^{\circ} \mathrm{C}$ dan asam asetat untuk menghilangkan katalis, metanol dan pengotor lainnya. Kemudian dikeringkan dalam vakum oven selama 30 menit dengan suhu $105^{\circ} \mathrm{C}$ untuk mengurangi kadar air.

b. Transesterifikasi menggunakan iradiasi microwave tanpa katalis

Minyak nyamplung sebanyak $200 \mathrm{~mL}$ dimasukkan kedalam reaktor dan ditambahkan $86 \mathrm{~mL}$ metanol, kemudian dipanaskan di dalam microwave menggunakan power $100 \mathrm{~W}$ selama 10 menit dengan pengambilan sampel setiap 2 menit sekali pada suhu $65^{\circ} \mathrm{C}$. Selanjutnya, campuran dimasukkan ke dalam corong pisah dan didiamkan sebelum gliserol dipisahkan dari bagian bawah corong pisah untuk mendapatkan lapisan biodiesel di bagian atas. Lapisan biodiesel dicuci dengan aquades hangat. Kemudian dikeringkan dalam microwave dengan suhu $105^{\circ} \mathrm{C}$ untuk mengurangi kadar air. Transesterifikasi dilakukan dengan kecepatan pengadukan $400 \mathrm{rpm}$ pada tekanan $1 \mathrm{~atm}$ dengan variasi power microwave $(100 \mathrm{~W}, 200 \mathrm{~W}$ dan $400 \mathrm{~W})$, variasi suhu reaksi $\left(50^{\circ} \mathrm{C}, 55^{\circ} \mathrm{C}, 60^{\circ} \mathrm{C}\right.$, $65{ }^{\circ} \mathrm{C}$ dan $70{ }^{\circ} \mathrm{C}$ ) dan variasi waktu reaksi $(5,7,10,12$ dan 15 menit). Proses transesterifikasi akan memperoleh data konsentrasi metil ester selama reaksi berlangsung.

c. Transesterifikasi menggunakan iradiasi microwave

Sebanyak $200 \mathrm{~mL}$ minyak nyamplung dimasukkan kedalam reaktor microwave. 1,874 gram katalis $\mathrm{KOH}(1 \% \mathrm{wt})$ dilarutkan dalam $86 \mathrm{~mL}$ metanol. Campuran katalis dan metanol dimasukkan ke dalam reaktor microwave berisi minyak nyamplung, dilanjutkan dengan pemanasan pada suhu $65{ }^{\circ} \mathrm{C}$. Pemanasan campuran di dalam microwave menggunakan power $100 \mathrm{~W}$ selama 5 menit dengan pengambilan sampel setiap 1 menit sekali. Selanjutnya, campuran dimasukkan ke dalam corong pisah dan didiamkan sebelum gliserol dipisahkan dari bagian bawah corong pisah untuk mendapatkan lapisan biodiesel di bagian atas. Lapisan biodiesel dicuci dengan aquades hangat. Kemudian dikeringkan dalam microwave dengan suhu $105^{\circ} \mathrm{C}$ untuk mengurangi kadar air. Transesterifikasi dilakukan dengan kecepatan pengadukan $400 \mathrm{rpm}$ pada tekanan $1 \mathrm{~atm}$ dengan variasi power microwave $(100 \mathrm{~W}, 200 \mathrm{~W}$ dan $400 \mathrm{~W})$, variasi suhu reaksi $\left(50^{\circ} \mathrm{C}, 55^{\circ} \mathrm{C}, 60^{\circ} \mathrm{C}\right.$, $65{ }^{\circ} \mathrm{C}$ dan $70{ }^{\circ} \mathrm{C}$ ) dan variasi waktu reaksi $(5,7,10,12$ dan 15 menit). Proses transesterifikasi akan memperoleh data konsentrasi metil ester selama reaksi berlangsung.

\section{Analisis Data}

Analisis data dilakukan dengan metode deskriptif menggunakan grafis secara regresi linier.

Data kinetika reaksi dalam percobaan ini adalah konsentrasi metil ester yang terbentuk selama reaksi berlangsung yang diperoleh dari hasil analisis menggunakan GC Hawlett Packard 5890 Series II. Plot grafik $\ln \mathrm{d}[\mathrm{ME}] / \mathrm{dt}$ versus $\ln [\mathrm{ME}]$ dibuat untuk menghitung $\mathrm{R}^{2}$ yang akan mengindikasikan keakuratan model kinetika reaksi (Nautiyal, et al., 2014). Penentuan harga $\mathrm{k}$ dari grafik hubungan konsentrasi metil ester terhadap waktu. Pendekatan ini juga dilaporkan dalam beberapa studi literatur (Sahirman, dkk, 2009; Kafuku, 2010; Jain et al., 2011; Shah, et al., 2013).

Dalam percobaan ini dilakukan reaksi transesterifikasi secara konvensional menggunakan katalis $\mathrm{KOH}$ dan reaksi transesterifikasi menggunakan iradiasi microwave tanpa katalis. Dari data percobaan akan dibandingkan energi aktivasi yang dibutuhkan selama reaksi transesterifikasi. Transesterifikasi dengan metode konvensional terjadi karena reaksi kimia akibat penambahan zat kimia berupa katalis. Transesterifikasi dengan iradiasi microwave terjadi karena reaksi fisika akibat panjang gelombang yang dipancarkan oleh microwave dan daya microwave yang menyebabkan perubahan suhu. Reaksi transesterifikasi menggunakan microwave dilakukan pada beberapa variasi daya microwave, variasi suhu dan variasi waktu.

Grafik hubungan ln $\mathrm{k}$ versus 1/T digunakan untuk menentukan energi aktivasi dan faktor tumbukan menggunakan persamaan Arrhenius sebagai berikut:

$$
\mathrm{k}=\mathrm{A} \exp (-\mathrm{Ea} / \mathrm{RT})
$$

dimana A adalah faktor tumbukan (L/mol.detik), Ea adalah energi aktivasi $(\mathrm{kJ} / \mathrm{mol})$ dan $\mathrm{R}$ adalah tetapan gas ideal (8,314 L.atm/mol.K).

Laju reaksi transesterifikasi dapat ditentukan dari persamaan laju reaksi :

$$
\mathrm{r}_{\text {trans }}=\mathrm{k}[\mathrm{ME}]_{\mathrm{t}}
$$

\section{Analisis Kualitas Produk}

Parameter biodiesel dari minyak nyamplung yang diuji antara lain bilangan asam, densitas, viskositas kinematik, flash point dan nilai kalor. Penentuan flash point dan nilai kalor dilakukan di Laboratorium Teknologi Minyak Bumi Gas dan Batubara Fakultas Teknik Kimia Universitas Gajah Mada. 
Setiap hasil biodiesel dari reaksi transesterifikasi ditentukan yield biodiesel dengan menggunakan persamaan :

Yield biodiesel $=\frac{\text { massa biodiesel }}{\text { massa minyak nyamplung }} \times 100 \%$

(Nautiyal, et al., 2014)

\section{ANALISIS DAN PERANCANGAN}

Pada penelitian ini dilakukan reaksi transesterifikasi dengan metode konvensional, iradiasi microwave tanpa katalis dan iradiasi microwave dengan katalis. Minyak yang digunakan untuk reaksi transesterifikasi adalah minyak nyamplung yang telah mengalami proses pretreatment yang terdiri dari beberapa tahap yaitu degumming, esterifikasi dan netralisasi. Proses pretreatment dilakukan pada minyak nyamplung karena memiliki kandungan FFA yang sangat tinggi sebesar $27,498 \%$ dan viskositas $54,0887 \mathrm{~mm}^{2} / \mathrm{s}$.

Tahap pretreatment yang diberikan terhadap minyak nyamplung adalah proses deguming menggunakan $2 \% \mathrm{v} / \mathrm{v}$ asam fosfat. Proses deguming dilakukan pada suhu $80{ }^{\circ} \mathrm{C}$ selama 15 menit disertai pengadukan. Kemudian minyak dimasukkan ke dalam corong pisah untuk mengendapkan gum dari minyak. Dari percobaan ini diperoleh gum yang kental berwarna kuning kecokelatan dan mengendap didasar corong pisah. Gum yang sangat kental menyebabkan corong menjadi tersumbat dan menjadi kesulitan minyak untuk melewati corong pisah. Perbedaan warna minyak nyamplung hasil proses deguming terhadap minyak nyamplung murni disajikan pada Gambar 2.

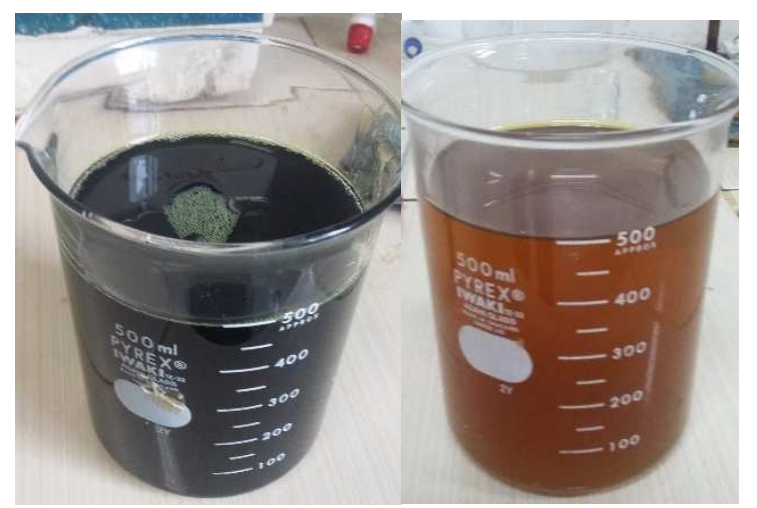

(a)

(b)

Gambar 2. (a) Minyak nyamplung murni (b). setelah degumming

Minyak nyamplung murni berwarna hijau kehitaman, kental dan berbau menyengat, setelah proses deguming menjadi oranye kecokelatan. Hal ini disebabkan karena pudarnya warna klorofil yang ada. Selain klorofil, minyak nyamplung juga memiliki pigmen karotenoid yang berwarna oranye, sehingga setelah proses pemanasan pigmen klorofil mengalami kerusakan dan pigmen karotenoid menjadi lebih dominan sehingga menjadi oranye kecokelatan. Minyak nyamplung setelah proses degumming memiliki kandungan FFA $25,521 \%$ dan viskositas $43,8484 \mathrm{~mm}^{2} / \mathrm{s}$. Penurunan viskositas disebabkan karena berkurangnya getah dan impuritas sebagai akibat proses deguming. Berdasarkan data tersebut menunjukkan bahwa proses deguming cukup efektif untuk menghilangkan getah dan impuritas yang terdapat dalam minyak nyamplung.

Proses esterifikasi pada penelitian ini dilakukan dua tahap karena kandungan FFA minyak nyamplung setelah degumming yang masih tinggi sebesar $25,521 \%$. Keberhasilan proses esterifikasi ditentukan oleh penurunan kadar FFA, sehingga perlu dilakukan pengukuran kadar FFA setelah esterifikasi. Produk minyak esterifikasi pertama memiliki kadar FFA sebesar 13,19\% dan minyak esterifikasi kedua memiliki FFA sebesar 5,94\% Produk proses esterifikasi pertama dan kedua minyak nyamplung dapat dilihat pada Gambar 3.

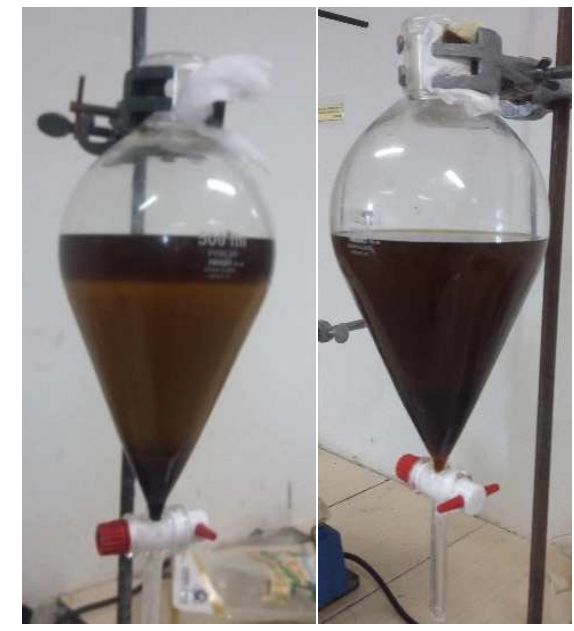

(a)

(b)

Gambar 3. (a).Hasil esterifikasi pertama (b).Hasil esterifikasi kedua Setelah melalui proses esterifikasi kadar FFA masih tinggi sebesar 5,94\%. Apabila kadar FFA $>2 \%$, maka reaksi transesterifikasi dengan katalis basa akan menyebabkan reaksi penyabunan. Sehingga diperlukan tahap netralisasi untuk menurunkan kadar FFA dan menetralkan minyak. Minyak hasil netralisasi berwarna kuning kecokelatan dengan kadar FFA sebesar $1,269 \%$.

\section{Reaksi transesterifikasi dengan metode konvensional}

Reaksi transesterifikasi dengan metode konvensional dilakukan pada beberapa variasi suhu $\left(50{ }^{\circ} \mathrm{C}, 55^{\circ} \mathrm{C}, 60\right.$ ${ }^{\circ} \mathrm{C}, 65^{\circ} \mathrm{C}$ dan $70{ }^{\circ} \mathrm{C}$ ) untuk mengetahui pengaruh suhu terhadap yield biodiesel yang dihasilkan dan untuk menghitung energi aktivasi reaksi. Reaksi transesterifikasi dilakukan dengan rasio molar minyak terhadap metanol 1:8 sesuai dengan penelitian Venkana \& Reddy (2009) dan Prihanto (2013) pada pembuatan biodiesel dari minyak nyamplung pada rasio molar metanol terhadap minyak 8:1 memberikan yield yang optimal. Katalis $\mathrm{KOH}$ yang digunakan pada reaksi transesterifikasi ini sebesar $1 \%$ wt dari minyak nyamplung yang digunakan. Proses transesterifikasi dilakukan dengan pengadukan $400 \mathrm{rpm}$ pada tekanan 1 atm selama 30 menit. 
Tabel 1. Hasil percobaan transesterifikasi dengan

\begin{tabular}{|l|l|l|l|l|}
\hline $\begin{array}{l}\text { Suhu } \\
\left({ }^{\circ} \mathrm{C}\right)\end{array}$ & $\begin{array}{l}\text { Yield } \\
(\%)\end{array}$ & $\begin{array}{l}\text { Densitas } \\
(\mathrm{g} / \mathrm{mL})\end{array}$ & $\begin{array}{l}\text { Viskositas } \\
\left(\mathrm{mm}^{2} / \mathrm{s}\right)\end{array}$ & $\begin{array}{l}\text { Bilangan } \\
\text { asam } \quad(\mathrm{mg} \\
\mathrm{KOH} / \mathrm{g})\end{array}$ \\
\hline 50 & 70,99 & 0,899 & $4,59,29$ & 0,5611 \\
\hline 55 & 72,66 & 0,89 & 4,3408 & 0,4910 \\
\hline 60 & 73,67 & 0,885 & 4,0341 & 0,5611 \\
\hline 65 & 77,15 & 0,887 & 4,0022 & 0,4910 \\
\hline 70 & 75,26 & 0,887 & 3,6850 & 0,42018 \\
\hline SNI & & $0,85-$ & $2,3-6,0$ & Maksimal 0,8 \\
& & 0,89 & & \\
\hline
\end{tabular}

Tabel diatas menunjukkan bahwa semakin tinggi suhu, maka yield biodiesel semakin meningkat dan viskositas semakin menurun dengan diikuti penurunan bilangan asam. Densitas, viskositas dan bilangan asam dari biodiesel yang dihasilkan dengan metode konvensional sebagian besar sudah memenuhi standar SNI 04-71822006.

Biodiesel minyak nyamplung yang dihasilkan pada penelitian ini berwarna coklat bening seperti warna teh, tidak seperti biodiesel pada umumnya berwarna kuning bening. Hal ini dikarenakan proses pretreatment biodiesel yang terlalu lama melalui proses pemanasan dari deguming, esterifikasi dan netralisasi yang menyebabkan warna menjadi gelap.

Grafik pengaruh suhu reaksi terhadap yield biodiesel pada reaksi transesterifikasi menggunakan metode konvensional disajikan pada Gambar 4:

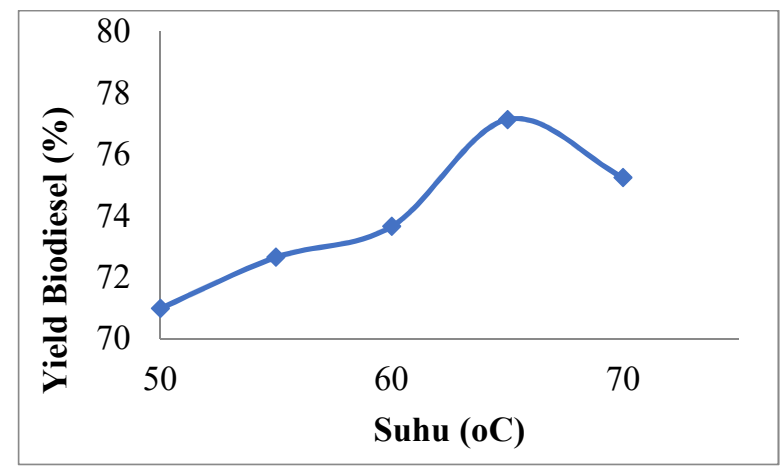

Gambar 4. Pengaruh suhu reaksi terhadap yield biodiesel pada metode konvensional

Gambar diatas menunjukkan kecenderungan bahwa semakin tinggi suhu, maka semakin besar yield biodiesel. Peningkatan yield terjadi pada suhu $50{ }^{\circ} \mathrm{C}$ hingga suhu $65{ }^{\circ} \mathrm{C}$ dari $70,99 \%$ hingga $77,15 \%$, tetapi yield biodiesel menurun pada suhu $70^{\circ} \mathrm{C}$ sebesar $75,26 \%$. Semakin tinggi suhu akan meningkatkan aktivitas katalistik. Hal ini sesuai dengan hasil penelitian Leung et al. (2010) bahwa peningkatan suhu reaksi dapat menurunkan viskositas minyak karena kelarutan trigliserida dalam metanol meningkat akibat meningkatnya energi kinetik antara molekul trigliserida dan metanol, sehingga laju reaksi meningkat. Peningkatan suhu reaksi dapat meningkatkan jumlah tumbukan efektif untuk menghasilkan biodiesel, tetapi pada suhu $70^{\circ} \mathrm{C}$ yield biodiesel menurun. Hal ini dikarenakan terjadinya reaksi samping yaitu polimerisasi dan saponifikasi trigliserida yang semakin cepat (Leung and Guo, 2006).

Keakuratan model kinetika reaksi ditentukan dengan membuat grafik hubungan $\ln [\mathrm{ME}]$ versus $\ln \mathrm{d}[\mathrm{ME}] / \mathrm{dt}$ yang disajikan pada Gambar 5:

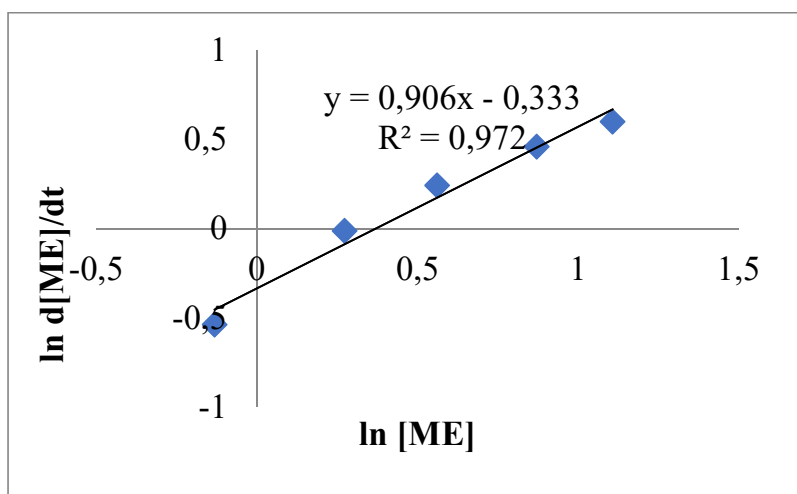

Gambar 5. Grafik hubungan ln [ME] versus ln d[ME]/dt

Dari Gambar diatas diperoleh persamaan $\ln$ $\mathrm{d}[\mathrm{ME}] / \mathrm{dt}=0,906 \quad \ln [\mathrm{ME}]-0,333 \quad\left(\mathrm{R}^{2}=0,972\right) \quad$ yang menunjukkan bahwa laju reaksi bervariasi secara linear dengan yield. Model kinetika reaksi orde satu memiliki keakuratan yang tinggi karena nilai $\mathrm{R}^{2}$ mendekati 1 . Penentuan harga $\mathrm{k}$ dari grafik hubungan waktu dengan $\ln [\mathrm{ME}]_{\mathrm{t}} /[\mathrm{ME}]_{0}$ yang disajikan pada Gambar 6:

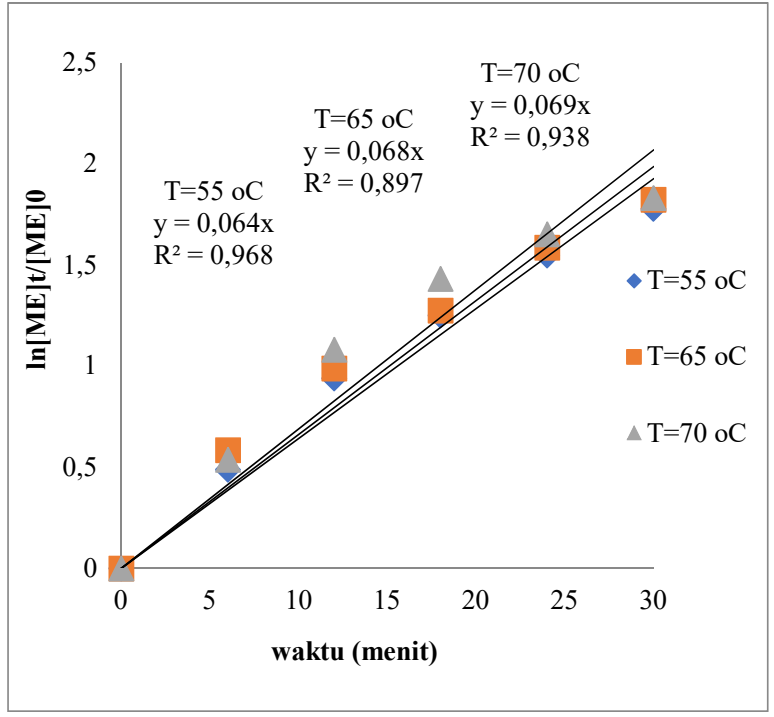

Gambar 6. Grafik hubungan waktu dengan ln $[\mathrm{ME}]_{\mathrm{t}} /[\mathrm{ME}]_{0}$

Dari Gambar 6 diatas diperoleh tetapan laju reaksi (k) pada suhu $55^{\circ} \mathrm{C}, 65^{\circ} \mathrm{C}$ dan $70{ }^{\circ} \mathrm{C}$ berturut-turut sebesar 0,064 menit ${ }^{-1}, 0,068$ menit $^{-1}$ dan 0,069 menit ${ }^{-1}$.

Energi aktivasi reaksi (Ea) dan faktor tumbukan (A) ditentukan dari grafik hubungan $\ln \mathrm{k}$ versus $1 / \mathrm{T}$ yang disajikan pada Gambar 7. 


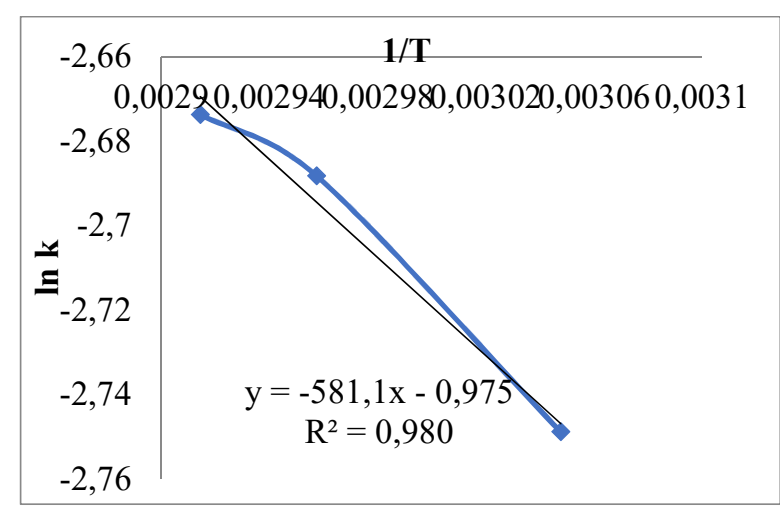

Gambar 7. Grafik hubungan ln k versus 1/T

Dari Gambar 7 diperoleh persamaan $\mathrm{y}=-581,1 \mathrm{x}$ 0,975 , sehingga diperoleh $\ln A=-0,975$, maka faktor tumbukan (A) sebesar $0,3772 \mathrm{~L} / \mathrm{mol}$ menit. Nilai $\mathrm{Ea} / \mathrm{R}=581,1$, dengan $\mathrm{R}=8,314$ sehingga diperoleh energi aktivasi (Ea) sebesar 4831,265 J/mol. Laju reaksi transesterifikasi $\mathrm{r}_{\text {trans }}=0,3772^{(-4831,265 / \mathrm{RT})}[\mathrm{ME}]$.

\section{Reaksi transesterifikasi dengan iradiasi microwave tanpa katalis}

Reaksi transesterifikasi dengan iradiasi microwave tanpa katalis dilakukan pada beberapa variasi power $(100,200$ dan $400 \mathrm{~W})$, variasi waktu $(10,15,20,25$ dan 30 menit) dan variasi suhu $\left(50,55,60,65\right.$ dan $\left.70^{\circ} \mathrm{C}\right)$. Dari hasil penelitian diperoleh 2 lapisan reaktan dimana lapisan atas berwarna kekuningan berupa metanol dan lapisan bawah berwarna kecokelatan berupa minyak.

Hasil penelitian menunjukkan bahwa semakin tinggi power microwave, waktu reaksi akan semakin lama dan semakin meningkatnya suhu reaksi, menyebabkan semakin banyak metanol yang menguap. Penggunaan microwave dalam percobaan ini tidak dapat menggantikan peran katalis untuk mempercepat reaksi, terbukti pada waktu reaksi 30 menit biodiesel masih belum terbentuk. Peran microwave hanya sebagai pemanas saja. Karena tidak terbentuk biodiesel yang diharapkan maka tidak dapat dilakukan perhitungan data kinetika reaksi transesterifikasi dengan iradiasi microwave tanpa katalis.

\section{Reaksi transesterifikasi dengan iradiasi microwave dengan katalis}

Reaksi transesterifikasi dengan iradiasi microwave dengan katalis $1 \%$ wt minyak nyamplung dilakukan pada beberapa variasi power $(100 \mathrm{~W}, 200 \mathrm{~W}$ dan 400 W), variasi waktu (5 menit, 7 menit, 10 menit, 12 menit dan 15 menit $)$ dan variasi suhu $\left(50^{\circ} \mathrm{C}, 55^{\circ} \mathrm{C}, 60^{\circ} \mathrm{C}, 65\right.$ ${ }^{\circ} \mathrm{C}$ dan $\left.70{ }^{\circ} \mathrm{C}\right)$.

Menurut Freedman et al. (2009) bahwa katalis $\mathrm{NaOCH}_{3}$ lebih efektif daripada $\mathrm{NaOH}$ karena pencampuran $\mathrm{NaOH}$ dengan metanol dapat mereduksi air yang dihasilkan, hal ini akan mempengaruhi yield biodiesel karena reaksi hidrolisis (Guo, 2010). Sehingga katalis hidroksida harus dicampurkan ke dalam metanol sebelum direaksikan dengan minyak. Katalis yang digunakan dalam penelitian ini adalah $\mathrm{KOH}$ yang dilarutkan dalam metanol sebelum direaksikan dengan minyak nyamplung hasil pretreatment sehingga dihasilkan $\mathrm{KOCH}_{3}$.

Data penelitian berupa massa biodiesel kemudian digunakan untuk menghitung yield biodiesel menggunakan Persamaan (1). Hasil percobaan reaksi transesterifikasi menggunakan iradiasi microwave dengan katalis disajikan pada Tabel 2.

Tabel 2. Hasil percobaan transesterifikasi dengan microwave dengan katalis

\begin{tabular}{|c|c|c|c|c|c|c|}
\hline $\begin{array}{c}\text { Power } \\
(\mathrm{W})\end{array}$ & $\mathrm{t}$ & $\begin{array}{c}\mathrm{T} \\
\left({ }^{\circ} \mathrm{C}\right) \\
\end{array}$ & $\begin{array}{c}\text { Yield } \\
(\%)\end{array}$ & $\begin{array}{c}\rho \\
(\mathrm{g} / \mathrm{mL})\end{array}$ & $\begin{array}{l}\eta \\
\left(\mathrm{mm}^{2} / \mathrm{s}\right)\end{array}$ & $\begin{array}{l}\text { Bil. } \\
\text { asam }\end{array}$ \\
\hline 100 & 5 , & 65 & 73,116 & 0,884 & 3,695 & 0,421 \\
\hline 200 & 5, & 65 & 84,246 & 0,882 & 3,664 & 0,351 \\
\hline 400 & 5, & 65 & 82,458 & 0,878 & 3,575 & 0,491 \\
\hline 200 & 5 , & 65 & 84,621 & 0,881 & 4,133 & 0,491 \\
\hline 200 & 7 , & 65 & 81,043 & 0,883 & 4,161 & 0,491 \\
\hline 200 & $10^{\prime}$ & 65 & 80,481 & 0,882 & 3,664 & 0,631 \\
\hline 200 & $12^{\prime}$ & 65 & 81,707 & 0,880 & 3,637 & 0,701 \\
\hline 200 & $15^{\prime}$ & 65 & 78,890 & 0,880 & 3,658 & 0,631 \\
\hline 200 & 5 , & 50 & 75,389 & 0,883 & 4,299 & 0,491 \\
\hline 200 & 5, & 55 & 77,657 & 0,882 & 4,315 & 0,281 \\
\hline 200 & 5, & 60 & 79,810 & 0,885 & 4,225 & 0,421 \\
\hline 200 & 5 , & 65 & 84,151 & 0,881 & 4,134 & 0,491 \\
\hline 200 & 5 , & 70 & 74,194 & 0,880 & 4,321 & 0,491 \\
\hline
\end{tabular}

Keterangan:

$\mathrm{t}=$ waktu (menit); $\mathrm{T}=$ suhu; $\rho=$ densitas $;=$ =viskositas

Tabel diatas menunjukkan kecenderungan bahwa peningkatan power pada microwave akan meningkatkan yield biodiesel, menurunkan viskositas dan densitas biodiesel. Semakin lama waktu reaksi, yield biodiesel semakin berkurang diikuti dengan viskositas yang menurun dan bilangan asam yang semakin meningkat. Semakin tinggi suhu reaksi, yield biodiesel semakin meningkat diikuti dengan penurunan viskositas yang tidak signifikan dan bilangan asam yang cenderung naik turun. Hal ini dikarenakan terjadinya reaksi samping yaitu polimerisasi dan penyabunan trigliserida, sehingga viskositas biodiesel meningkat.

\section{Kinetika Reaksi Transesterifikasi}

Keakuratan model kinetika reaksi ditentukan dengan membuat grafik hubungan $\ln [\mathrm{ME}]$ versus $\ln \mathrm{d}[\mathrm{ME}] / \mathrm{dt}$ yang disajikan pada Gambar 8 . 


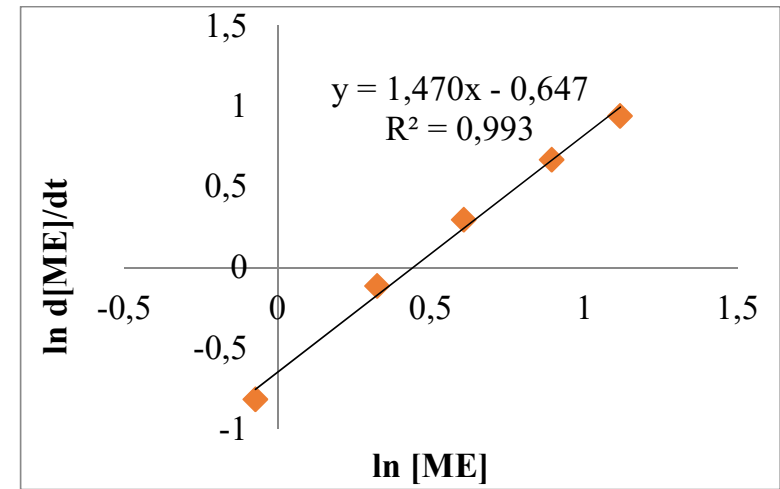

Gambar 8. Grafik hubungan $\ln [\mathrm{ME}]$ versus $\ln \mathrm{d}[\mathrm{ME}] / \mathrm{dt}$

Dari Gambar 4.16. diperoleh persamaan $\ln$ $\mathrm{d}[\mathrm{ME}] / \mathrm{dt}=1,470 \ln [\mathrm{ME}]-0,647$ yang menunjukkan bahwa laju reaksi bervariasi secara linear dengan yield. Dari Gambar 8. diperoleh nilai $\mathrm{R}^{2}$ sebesar 0,993, yang artinya model kinetika reaksi orde satu memiliki keakuratan yang tinggi karena mendekati 1. Penentuan harga $\mathrm{k}$ dari grafik hubungan waktu dengan $\mathrm{ln}$ $[\mathrm{ME}]_{\mathrm{t}} /[\mathrm{ME}]_{0}$ disajikan pada Gambar 9.

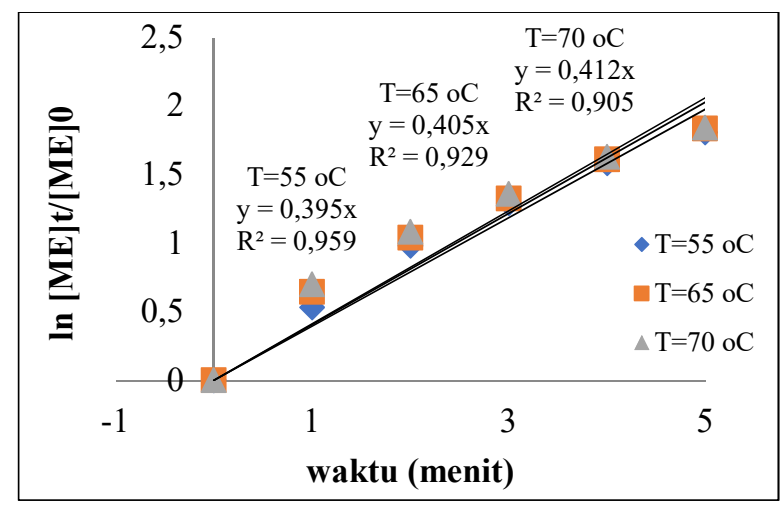

Gambar 9. Grafik hubungan waktu versus $\ln [\mathrm{ME}]_{\mathrm{t}} /[\mathrm{ME}]_{0}$

Gambar 9 menunjukkan bahwa dari ketiga garis tersebut hampir berimpit, sehingga harga k pada suhu 55,65 dan $70^{\circ} \mathrm{C}$ perbedaannya sangat kecil. Perbedaan yang sangat kecil ini disebabkan karena konsentrasi metil ester yang dihasilkan pada waktu yang sama pada suhu yang berbeda perbedaannya sangat kecil. Artinya perubahan suhu tidak signifikan terhadap perubahan harga $\mathrm{k}$, hal ini dikarenakan reaksi kimia yang tidak signifikan tetapi reaksi fisika dalam hal ini difusivitas dan interaksi medan elektromagnetik dengan molekul dalam media pereaksi (Perreux et al., 2013). Tetapan laju reaksi (k) pada suhu $55{ }^{\circ} \mathrm{C}, 65{ }^{\circ} \mathrm{C}$ dan $70{ }^{\circ} \mathrm{C}$ berturut-turut sebesar 0,395 menit $^{-1}, 0,405$ menit $^{-1}$ dan 0,412 menit $^{-1}$. Hal ini sesuai dengan teori Arrhenius bahwa semakin tinggi suhu maka semakin tinggi harga tetapan laju reaksinya. Harga tetapan laju reaksi menggunakan iradiasi microwave lebih besar dibandingkan dengan metode konvensional. Hal ini sesuai dengan penelitian Kumar et al. (2011) bahwa besarnya tetapan laju reaksi $(\mathrm{k})$ bervariasi tergantung pada komposisi asam lemak pada minyak yang digunakan, kondisi reaksi dan teknologi untuk produksi biodiesel.
Faktor tumbukan (A) dan energi aktivasi (Ea) ditentukan dengan membuat grafik hubungan antara ln $\mathrm{k}$ dengan 1/T yang disajikan pada Gambar 10 .

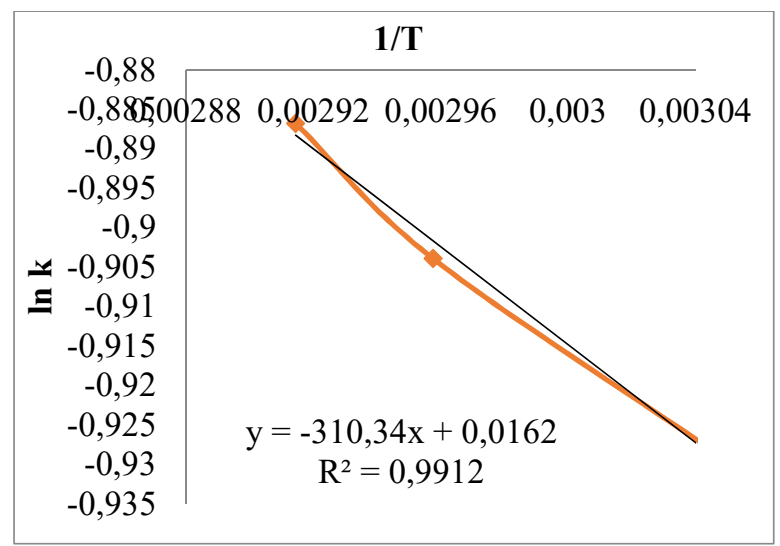

Gambar 10. Grafik ln k vs 1/T

Dari Gambar 10 diperoleh persamaan $y=-310,3 x+$ 0,016 sehingga diperoleh energi aktivasi (Ea) sebesar $2579,834 \mathrm{~J} / \mathrm{mol}$; faktor tumbukan (A) sebesar 1,0161 $\mathrm{L} / \mathrm{mol}$ menit dan laju reaksi transesterifikasi $\left.\left(\mathrm{r}_{\mathrm{t}}\right)=1,0161 \mathrm{e}^{(-2579,834 /} \mathrm{RT}\right)[\mathrm{ME}]$. Penggunaan iradiasi microwave menghasilkan faktor tumbukan yang lebih besar dibandingkan metode konvensional. Hal ini dikarenakan penggunaan microwave menyebabkan peningkatan mobilitas molekul reaktan yang mengarahkan pada kenaikan faktor tumbukan (Gude et al., 2013). Penurunan energi aktivasi pada microwave dikaitkan dengan peningkatan entropi (Mazubert et al., 2014). Peningkatan entropi sebagai akibat kenaikan suhu pada sistem tertutup di dalam microwave. Adanya gugus hidroksil $(\mathrm{OH})$ yang terkena radiasi microwave menyebabkan suhu di sekitar gugus $\mathrm{OH}$ menjadi lebih tinggi dari lingkungan sehingga energi aktivasi yang diperlukan untuk transesterifikasi menjadi lebih kecil (Lertsathapornsuk et al., 2008).

Hasil penelitian menunjukkan bahwa laju reaksi transesterifikasi menggunakan iradiasi microwave $\mathrm{r}_{\mathrm{t}}=1,0161 \mathrm{e}^{(-2579,834 / \mathrm{RT})}[\mathrm{ME}]$ lebih besar dibandingkan dengan laju reaksi transesterifikasi menggunakan metode konvensional $r_{t}=0,3772^{(-4831,265 / R T)}[\mathrm{ME}]$. Hal ini dikarenakan iradiasi gelombang microwave melibatkan polarisasi dipolar dan konduksi ionik. Frekuensi microwave yang tinggi menyebabkan perbedaan fase antar bidang dan orientasi dipol. Konduksi ionik terjadi akibat partikel terlarut berinteraksi di bawah pengaruh gelombang microwave. Ketika arah medan listrik berubah, konduksi ion berlangsung lambat dan akan mengubah energi kinetik menjadi energi panas yang disebabkan oleh gesekan (Lidström et al., 2001; Mingos \& Baghurst, 1991). Hal ini sesuai dengan penelitian Kappe et al. (2012) bahwa peningkatan laju reaksi dalam microwave karena fenomena termal yang disebabkan oleh mekanisme dielektrik microwave (penyerapan gelombang elektromagnetik dari microwave). 


\section{Hasil Analisis Biodiesel}

Sifat fisik biodiesel nyamplung dari iradiasi microwave dibandingkan dengan standar SNI 04-71822006,ASTM 6751-02 dan EN-14214 disajikan pada Tabel 4.4

Tabel 3. Sifat fisik biodiesel nyamplung dibandingkan SNI 047182-2006, ASTM 6751-02 dan EN-14214

\begin{tabular}{|c|c|c|c|c|}
\hline $\begin{array}{c}\text { Sifat } \\
\text { fisik }\end{array}$ & $\begin{array}{c}\text { Bio- } \\
\text { diesel }\end{array}$ & $\begin{array}{c}\text { SNI 04- } \\
7182- \\
2006\end{array}$ & $\begin{array}{c}\text { ASTM } \\
6751-02\end{array}$ & EN-14214 \\
\hline $\begin{array}{c}\text { Massa } \\
\text { jenis pada } \\
40^{\circ} \mathrm{C} \\
\left(\mathrm{kg} / \mathrm{m}^{3}\right)\end{array}$ & 881 & $850-890$ & $870-890$ & $860-900$ \\
\hline $\begin{array}{c}\text { Bilangan } \\
\begin{array}{c}\text { asam (mg } \\
\text { KOH/g) }\end{array}\end{array}$ & 0,491 & Maks.0,8 & Maks. 0,5 & Maks 0,5 \\
\hline $\begin{array}{c}\text { Viskositas } \\
\text { kinematik } \\
\text { suhu 40 } \\
(\mathrm{mm} / \mathrm{C})\end{array}$ & 4,133 & $2,3-6,0$ & $1,9-6,0$ & $3,5-5,0$ \\
\hline $\begin{array}{c}\text { Titik nyala } \\
\left({ }^{\circ} \mathrm{C}\right)\end{array}$ & 165 & Min. 100 & Min. 131 & Min.101 \\
\hline $\begin{array}{c}\text { Nilai kalor } \\
(\mathrm{BTU} / \mathrm{lb})\end{array}$ & 15.814 & Min. 15.047 Min.15.907 & Min.15.047 \\
\hline
\end{tabular}

Tabel 3 menunjukkan bahwa sebagian besar sifat fisik yang meliputi massa jenis, bilangan asam, viskositas kinematic, titik nyala dan nilai kalor biodiesel nyamplung dengan iradiasi microwave yang diuji telah memenuhi standar SNI 04-7182-2006, ASTM 6751-02 dan EN-14214.

Metil ester hasil reaksi transesterifikasi selanjutnya dianalisis menggunakan GC-MS untuk mengetahui metil ester apa saja yang terbentuk. Kromatogram GCMS dari minyak nyamplung menggunakan iradiasi microwave disajikan pada Gambar 11.

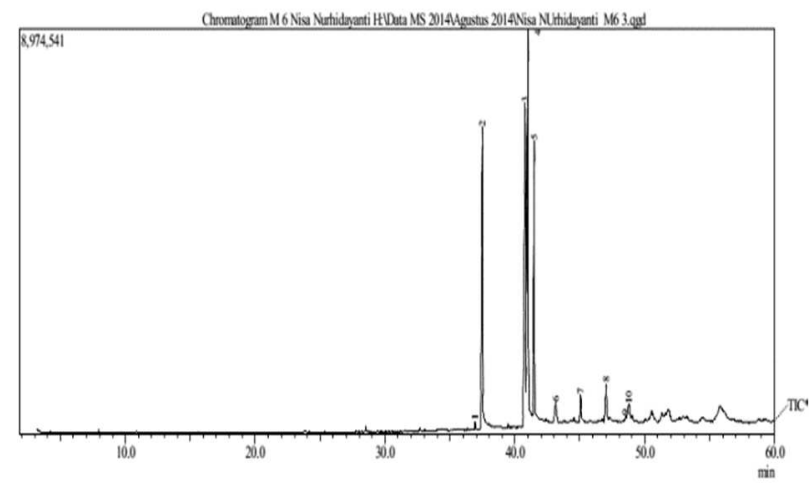

Gambar 11. Kromatogram GC-MS biodiesel nyamplung dengan iradiasi microwave

Gambar diatas menunjukkan kromatogram GC-MS biodiesel nyamplung dengan iradiasi microwave pada kondisi operasi terbaik yaitu pada power microwave 200W pada suhu $65^{\circ} \mathrm{C}$ selama 5 menit, yield biodiesel maksimal sebesar $84,62 \%$ dan sifat fisik biodiesel telah memenuhi standar SNI 04-7182-2006, ASTM 6751-02 dan EN-14214. Dari Gambar 11 diperoleh hasil GC-
MS dari biodiesel nyamplung dengan iradiasi microwave yang disajikan pada Tabel 4 .

Tabel 4. Hasil GC-MS dari biodiesel nyamplung dengan iradiasi microwave

\begin{tabular}{|c|c|c|c|c|}
\hline $\begin{array}{l}\text { Peak } \\
\#\end{array}$ & $\begin{array}{l}\text { Waktu } \\
\text { etensi }\end{array}$ & $(\%)$ & Nama senyawa & $\begin{array}{l}\text { Rumus } \\
\text { molekul }\end{array}$ \\
\hline 1 & $\begin{array}{l}36,91 \\
4\end{array}$ & 0,37 & Metil palmitoleat & $\mathrm{C}_{17} \mathrm{H}_{32} \mathrm{O}_{2}$ \\
\hline 2 & $\begin{array}{l}37,49 \\
8\end{array}$ & $\begin{array}{l}19,2 \\
1\end{array}$ & Metil palmitat & $\mathrm{C}_{17} \mathrm{H}_{34} \mathrm{O}_{2}$ \\
\hline 3 & $\begin{array}{l}40,78 \\
2\end{array}$ & $\begin{array}{l}25,7 \\
6\end{array}$ & $\begin{array}{l}\text { Metil-9,12- } \\
\text { heksadecadienoat }\end{array}$ & $\mathrm{C}_{17} \mathrm{H}_{30} \mathrm{O}_{2}$ \\
\hline 4 & $\begin{array}{l}41,00 \\
6\end{array}$ & $\begin{array}{l}30,2 \\
3\end{array}$ & Metil oleat & $\mathrm{C}_{19} \mathrm{H}_{36} \mathrm{O}_{2}$ \\
\hline 5 & $\begin{array}{l}41,48 \\
9\end{array}$ & $\begin{array}{l}15,7 \\
5\end{array}$ & Metil stearat & $\mathrm{C}_{19} \mathrm{H}_{38} \mathrm{O}_{2}$ \\
\hline 6 & $\begin{array}{l}43,14 \\
1\end{array}$ & 2,11 & Metil lignocerat & $\mathrm{C}_{25} \mathrm{H}_{50} \mathrm{O}_{2}$ \\
\hline 7 & $\begin{array}{l}45,04 \\
9\end{array}$ & 1,41 & Metil eicosanoat & $\mathrm{C}_{21} \mathrm{H}_{42} \mathrm{O}_{2}$ \\
\hline 8 & $\begin{array}{l}47,00 \\
4\end{array}$ & 3,05 & $\begin{array}{l}2,6,10,14,18,22- \\
\text { tetrakosaheksaene, } \\
2,6,10,15,19,23- \\
\text { heksametil- (CAS) } \\
\text { Squalene }\end{array}$ & $\mathrm{C}_{30} \mathrm{H}_{50}$ \\
\hline 9 & $\begin{array}{l}48,50 \\
0\end{array}$ & 0,54 & Metil behenate & $\mathrm{C}_{23} \mathrm{H}_{46} \mathrm{O}_{2}$ \\
\hline 10 & $\begin{array}{l}48,78 \\
1\end{array}$ & 1,57 & $\begin{array}{l}\text { 1,4- } \\
\text { bis(disikloheksilpo } \\
\text { spino)-butane }\end{array}$ & $\mathrm{C}_{28} \mathrm{H}_{52} \mathrm{P}_{2}$ \\
\hline
\end{tabular}

Tabel diatas menunjukkan bahwa senyawa penyusun dalam biodiesel nyamplung yang dominan adalah 30,23\%, metil-9-octadecenoate (metil oleat), metil9,12-heksadecadienoate (metil linolelaidate), 25,76\%, metil heksadecanoat (metil palmitat), 19,21\%, metil oktadecanoat (metil stearat), 15,75\%, 2,6,10,14,18,22tetracosaheksaene, 3,05\% 2,6,10,15,19,23-heksametil(CAS) Squalene, 2,11\% metil lignocerate, 1,57\% 1,4bis(dicyclohexylphosphino)-butane, $\quad 1,41 \%$ metil eikosanoat, $0,54 \%$ metil behenate dan $0,37 \%$ metil palmitoleat. Metil ester tersebut merupakan hasil konversi dari asam lemak penyusun trigliserida dalam minyak nyamplung dan bukan sebagai asam lemak bebasnya. Berdasarkan senyawa yang terkandung dalam metil ester tersebut dapat ditentukan senyawa yang terkandung dalam minyak yang digunakan sebagai bahan baku. Dalam bahan (minyak nyamplung) senyawa yang paling dominan adalah asam oleat yang membentuk ester metil oleat. Asam oleat merupakan asam lemak tak jenuh (memiliki satu ikatan rangkap dua pada rantai karbonnya).

Metil oleat yang memiliki persentase sebanyak 30,23\% menunjukkan bahwa asam oleat pada minyak juga tinggi. Hal ini sesuai dengan analisis Balitbanghut (2008), Sahirman (2009), Ramaraju and Ashok (2011) 
dan Silitonga et al. (2014) bahwa asam lemak dengan komposisi tertinggi yang terkandung dalam minyak nyamplung adalah asam oleat. Selain metil oleat diperoleh metil palmitat (metil-9,12heksadekadienoat) sebesar $25,76 \%$ yang terbentuk dari asam-9,12-heksadekadienoat yang memiliki dua ikatan rangkap dua pada rantai karbonnya. Dari hasil analisis ini maka disimpulkan bahwa minyak nyamplung yang digunakan sebagai bahan baku merupakan minyak dengan kandungan asam lemak tak jenuh yang lebih tinggi dibanding asam lemak jenuhnya.

\section{KESIMPULAN DAN SARAN}

\section{Kesimpulan}

Berdasarkan hasil penelitian ini dapat disimpulkan bahwa:

1. Analisis GCMS menunjukkan bahwa metil ester dari biodiesel minyak nyamplung adalah $30,23 \%$ metil oleat, $25,76 \%$ metil linolelaidat, $19,21 \%$ metil palmitat, $15,75 \%$ metil stearat, $2,11 \%$ metil lignocerat, $1,41 \%$ metil eicosanoat, $0,54 \%$ metil behenate dan $0,37 \%$ metil palmitoleat.

2. Biodiesel nyamplung dengan iradiasi microwave memiliki tetapan laju reaksi $(\mathrm{k})$ pada suhu $55^{\circ} \mathrm{C}, 65^{\circ} \mathrm{C}$ dan $70{ }^{\circ} \mathrm{C}$ berturutturut sebesar 0,395 menit $^{-1}, 0,405$ menit $^{-1}$ dan 0,412 menit $^{-1}$, energi aktivasi (Ea) sebesar $2579,834 \mathrm{~J} / \mathrm{mol}$, faktor tumbukan (A) sebesar $1,0161 \mathrm{~L} / \mathrm{mol}$ menit, laju reaksi transesterifikasi $\left(r_{t}\right)=1,0161 \mathrm{e}^{(-2579,834 / \mathrm{RT})}$ [ME]. Sedangkan biodiesel nyamplung dengan metode konvensional memiliki tetapan laju reaksi (k) untuk metode konvensional pada suhu $55^{\circ} \mathrm{C}, 65^{\circ} \mathrm{C}$ dan 70 ${ }^{\circ} \mathrm{C}$ berturut-turut sebesar 0,064 menit $^{-1}, 0,068$ menit $^{-1}$ dan 0,069 menit $^{-1}$ energi aktivasi $(\mathrm{Ea})$ sebesar 4831,265 J/mol, faktor tumbukan (A) sebesar $0,3772 \mathrm{~L} / \mathrm{mol}$ dan laju reaksi transesterifikasi $\left(\mathrm{r}_{\mathrm{t}}\right)=0,3772 \mathrm{e}^{(-4831,265 / \mathrm{RT})}[\mathrm{ME}]$.

3. Penggunaan iradiasi microwave dapat meningkatkan laju reaksi transesterifikasi, menurunkan energi aktivasi dan mengurangi waktu reaksi menjadi 1/6 kali lebih cepat dibandingkan metode konvensional.

\section{Saran}

Apabila pembuatan biodiesel dari minyak nyamplung dengan iradiasi microwave akan dikembangkan dalam skala industri maka perlu pengelolaan penyedia bahan baku yang baik dan instrumen yang memadai. Pemerintah diharapkan ikut berperan dalam mengoptimalkan lahan potensial untuk perkebunan tanaman nyamplung sehingga ketersediaan biji nyamplung dapat digunakan secara berkelanjutan.

\section{DAFTAR PUSTAKA}

Balitbanghut (Badan Penelitian dan Pengembangan Kehutanan). (2008). Nyamplung (Calophyllum inophyllum Linn) Sumber energi biofuel yang potensial: Jakarta.

Bankoviü-Iliü, I.B., Stamenkoviü, O.S., and Veljkoviü, V.B. (2012). Biodiesel production from non-edible plant oils. Renewable and Sustainable Energy Reviews (16): 3621-3647.

Demirbas A. (2009). Progress and recent trends in biodiesel fuels. Energy Conversion and Management (50): 14-34.

Eevera, T., Rajendran, K., and Saradha, S. (2009). Biodiesel production process optimization and characterization to assess the suitability of the product for varied environmental conditions. Renewable Energy (34): 762-765.

Freedman, B., Pryde, E.H., and Mounts, T.L. (2009). Variables affecting the yields of fatty esters from transesterified vegetable oils. J Am Oil Chem Soc (61): 1638-43.

Gude, V.G., Patil, P., Martinez, G.E., Deng, S., and Nirmalakhandan, N. (2013) Microwave energy potential for biodiesel production. Sustainable Chemical Process (1): 1-31.

Guo, Y. (2010). Alkaline-catalyzed production of biodiesel fuel from virgin canola oil and recycled waste oils. PhD dissertation, Department of Mechanical Engineering, the University of Hong Kong, Hong Kong. p. 184.

Jain, S., Sharma, MP. and Rajvanshi, S. (2011). Acid base catalyzed transesterification kinetics of waste cooking oil. Fuel Processing Technology (92): 32-38.

Kafuku, G., and Mbarawa, M. (2010). Biodiesel production from Croton megalocarpus oil and its process optimization. Fuel, 89(9): 2556-2560.

Kappe, C.O, and Stadler, A. (2005). Microwave in Organic and Medical Chemistry. WILEY.

Kumar, R., Ravi Kumar. G., and Chandrashekar, N. (2011). Microwave assisted alkali catalyzed transesterification of Pongamia pinnata seed oil for biodiesel production. Bioresource Technology (102): 6617-6620.

Lertsathapornsuk, V., Pairintra, R., Aryusuk, K., and Krisnangkura, K. (2008) Microwave assisted in continuous biodiesel production from waste frying palm oil and its performance in a $100 \mathrm{~kW}$ diesel generator. Fuel Process Technology (89): 1330-1336.

Lidstrom P, Tierney J, Wathey B, and Westman J. (2001). Microwave assisted organic synthesis - a review. Tetrahedron (57): 9225-9283.

Mazubert, A., Taylor, C., Aubin, J., and Poux, M. (2014). Key role of temperature monitoring in interpretation of microwave effect on transesterification and esterification reactions for 
biodiesel production. Bioresource Technology (161): 270-279.

Mingos, D.M.P., \& Baghurst, D.R. (1991). Tilden lecture. Applications of microwave dielectric heating effects to synthetic problems in chemistry. Chemistry Society Review (20): 1-47.

Motasemi, F., and Ani, F. N. (2012). A review on microwave-assisted production of biodiesel. Renewable and Sustainable Energy Reviews, 16(7): 4719-4733.

Nautiyal, P., Subramanian, K.A., and Dastidar, M.G. (2014). Kinetic and thermodynamic studies on biodiesel production from Spirulina platensis algae biomass using single stage extractiontransesterification process. Fuel (135): 228-234

Ong, H.C., Masjuki, H.H., Mahlia, T.M.I, Silitonga, A.S, Chong, W.T., and Leong K.Y. (2014). Optimization of biodiesel production and engine performance from high free fatty acid Calophyllum inophyllum oil in CI diesel engine. Energy Conversion and Management (81): 3040.

Perreux, L., Loupy, A., and Petit, A., (2013). Nonthermal effects of microwaves in organic synthesis. In: Microwaves in Organic Synthesis, third ed. Wiley VCH, Weinheim, pp. 127-208.

Prihanto, A., Pramudono, B. dan Santosa, H. (2013). Peningkatan Yield Biodiesel dari Minyak Biji Nyamplung melalui Transesterifikasi dua Tahap. Momentum, Vol. 9, No. 2, Oktober 2013, Hal. 46-53 ISSN 0216-7395.

Priambodo, R., Chen, T.C., Lu, M.C., Gedanken, A., Liao, JD., and Huang, YH. (2015). Novel Technology for Bio-diesel Production from Cooking and Waste Cooking Oil by Microwave Irradiation. The $7^{\text {th }}$ International Conference on Applied Energy - ICAE2015. Energy Procedia (75): 84-91.

Pusat Penelitian dan Pengembangan Hasil Hutan (P3HH). (2005-2008). Penelitian Pembuatan Biodiesel dari Biji Nyamplung (Calophyllum inophyllum Linn.). http://www.litbang. pertanian.go.id/

Ramaraju A., and Ashok K.T.V. (2011). Biodiesel development from high free fatty acid punnaka oil. Journal engineering application science 6(4): 1-6

Ridho, M.F., Jatranti, S., Qadariyah, L. dan Mahfud. (2014). Pembuatan Biodiesel dari Minyak Nyamplung Menggunakan Pemanasan Gelombang Mikro. Jurnal teknik Pomits Vol. 3, No. 2, ISSN: 2337-3539 (2301-9271 Print).

Sahirman. (2009). Perancangan Proses Produksi Biodiesel dari Minyak Biji Nyamplung (Calophyllum inophyllum L.). Institut Pertanian Bogor: Award Disertasi.
Sahirman, Suryani, A., Mangunwidjaja, D., Sukardi dan Sudradjat, R. (2009). Kinetika Reaksi Transesterifikasi Minyak Biji Nyamplung (Calophyllum inophyllum) pada Proses Produksi Biodiesel. Jurnal Penelitian Hasil Hutan Pusat Penelitian dan Pengembangan Hasil Hutan: Bogor.

Sahoo, P.K., and Das, L.M. (2009). Process optimization for biodiesel production from jatropha, karanja and polanga oils. Fuel 88 (9) : 1588-1594.

Sathyaselvabala, V., Ponnusamy, S., Periyaraman, P.M., Selvaraj, D.K., Thangaraj, V., and Subramanian, S. (2011). Two step biodiesel production from Calophyllum inophyllum oil: studies on thermodynamic and kinetic modelling of modified $\beta$-zeolite catalysed pretreatment. Journal Chemical Engineering (9999) : 1-8.

Shah, K.A., Jigisha, K.P., and Kalpana, C.M. (2013). Optimization studies and chemical kinetics of silica sulfuric acid-catalyzed biodiesel synthesis from waste cooking oil. BioEnergy Resourch :111.

Sharma, YC., Singh, B,. and Upadhyay, SN. (2011). Advancements in development and characterization of biodiesel: a review. Fuel (87):2355-2373.

Silitonga, A.S., Masjuki, H.H., Mahlia, T.M.I., Ong, H.C., Chong, W.T., and Boosroh MH. (2013). Overview properties of biodiesel diesel blends from edible and non-edible feedstock. Renewable and Sustainable Energy Reviews (22) :346-60.

Silitonga, A.S., Ong,H.C., Mahlia, T.M.I., Masjuki, H.H., and Chong, W.T. (2014). Biodiesel conversion from high FFA crude Jatropha curcas, Calophyllum inophyllum and Ceiba pentandra oil.. Energy Procedia (61) : 480 - 483.

Sugiyono, A. I., Anindhita, Boedoyo, M.S., dan Adiarso. (2014). Outlook Energi Indonesia 2014, Pengembangan Energi Untuk Mendukung Program Substitusi BBM. Badan Pengkajian dan Penerapan Teknologi (BPPT): Jakarta.

Venkanna, B.K., and Reddy, V.C. (2009). Biodiesel production and optimization from Calophyllum inophyllum linn. oil (honne oil) - a three stage method. Bioresource Technology (100) : 51225125 .

Zhang, S., Zu, Y.G., Fu, Y.J., Luo, M., Zhang, D.Y., and Thomas, E. (2010). Rapid microwave assisted transesterification of yellow horn oil to biodiesel using a heteropolyacid solid catalyst. Bioresource Technology (101): 931-936. 